\title{
Functionalization of Pentaphosphorus Cations by Complexation**
}

\author{
Anup K. Adhikari, Christoph G. P. Ziegler, Kai Schwedtmann, Clemens Taube, Jan. J. Weigand,* \\ and Robert Wolf*
}

\begin{abstract}
The chemistry of polyphosphorus cations has rapidly developed in recent years, but their coordination behavior has remained mostly unexplored. Herein, we describe the reactivity of $\left[P_{5} R_{2}\right]^{+}$cations with cyclopentadienyl metal complexes. The reaction of $\left[\mathrm{Cp}^{\mathrm{Ar}} \mathrm{Fe}(\mu-\mathrm{Br})\right]_{2}\left(\mathrm{Cp}^{\mathrm{Ar}}=\mathrm{C}_{5}\left(\mathrm{C}_{6} \mathrm{H}_{4^{-}}\right.\right.$ 4-Et $\left.)_{5}\right)$ with $\left[\mathrm{P}_{5} \mathrm{R}_{2}\right]\left[\mathrm{GaCl}_{4}\right]\left(\mathrm{R}=\mathrm{iPr}\right.$ and 2,4,6- $\left.\mathrm{Me}_{3} \mathrm{C}_{6} \mathrm{H}_{2}(\mathrm{Mes})\right)$ afforded bicyclo[1.1.0]pentaphosphanes (1-R, $R=i P r$ and Mes), showing an unsymmetric "butterfly" structure. The same products $\mathbf{1 - R}$ were formed from $K\left[\mathrm{Cp}^{\mathrm{Ar}}\right]$ and $\left[\mathrm{P}_{5} \mathrm{R}_{2}\right]\left[\mathrm{GaCl}_{4}\right]$. The cationic complexes $\left[C p^{A r} \mathrm{Co}\left(\eta^{4}-P_{5} R_{2}\right)\right]\left[G a C l_{4}\right]$ (2- $\boldsymbol{R}$ $\left[\mathrm{GaCl}_{4}\right], \mathrm{R}=\mathrm{iPr}$ and $\left.\mathrm{Cy}\right)$ and $\left[\left(\mathrm{Cp}^{\mathrm{Ar}} \mathrm{Ni}\right)_{2}\left(\eta^{3: 3}-\mathrm{P}_{5} \mathrm{R}_{2}\right)\right]\left[\mathrm{GaCl} \mathrm{Cl}_{4}\right]$ (3-R $\left.\left[\mathrm{GaCl}_{4}\right]\right)$ were obtained from $\left[\mathrm{P}_{5} R_{2}\right]\left[\mathrm{GaCl}_{4}\right]$ and $\left[\mathrm{Cp}^{\mathrm{Ar}} \mathrm{M}\right.$ $(\mu-B r)]_{2} \quad(M=C o$ and $N i)$ as well as by using low-valent "C ${ }^{A r} M^{I}$ " sources. Anion metathesis of $\mathbf{2}-\boldsymbol{R}\left[\mathrm{GaCl}_{4}\right]$ and 3-R $\left[\mathrm{GaCl}_{4}\right]$ was achieved with $\mathrm{Na}\left[\mathrm{BArF} \mathrm{F}_{24}\right]$. The $P_{5}$ framework of the resulting salts $\mathbf{2}-\boldsymbol{R}\left[B A r F_{24}\right]$ can be further functionalized with nucleophiles. Thus reactions with $\left[E t_{4} N\right] X$ $(X=C N$ and $C l)$ give unprecedented cyano- and chlorofunctionalized complexes, while organo-functionalization was achieved with $\mathrm{CyMgCl}$.
\end{abstract}

Because of the large $\mathrm{P}-\mathrm{P}$ single bond energy (ca. $200 \mathrm{~kJ} \mathrm{~mol}^{-1}$ in typical compounds), the structural diversity of polyphosphorus derivatives is unrivalled in main group chemistry. ${ }^{[1-6]}$ Seminal contributions of Baudler, von Schnering, and many others have unraveled a plethora of neutral polyphosphanes and polyphosphanide anions, ${ }^{[2-5]}$ and the coordination behavior of such species has been investigated extensively in the past. ${ }^{[5,6]}$ Transition-metal polyphosphides such as pentamethylpentaphosphaferrocene are used as building blocks for $1 \mathrm{D}$ and $2 \mathrm{D}$ polymers and spherical supramolecules. $^{[7,8]}$ Alkylation, protonation, halogenation,

[*] Dr. A. K. Adhikari, C. G. P. Ziegler, Prof. Dr. R. Wolf Institute of Inorganic Chemistry, University of Regensburg 93040 Regensburg (Germany)

E-mail: robert.wolf@ur.de

Dr. K. Schwedtmann, C. Taube, Prof. Dr. J. J. Weigand

Faculty of Chemistry and Food Chemistry, TU Dresden

01062 Dresden (Germany)

E-mail: jan.weigand@tu-dresden.de

[***] A previous version of this manuscript has been deposited on a preprint server (https://doi.org/10.26434/chemrxiv.8940083.v1).

D. Supporting information and the ORCID identification number(s) for

(iD) the the author(s) of this article can be found under: https://doi.org/10.1002/anie.201908998.

of (c) 2019 The Authors. Published by Wiley-VCH Verlag GmbH \& Co. $\mathrm{KGaA}$. This is an open access article under the terms of the Creative Commons Attribution Non-Commercial License, which permits use, distribution and reproduction in any medium, provided the original work is properly cited, and is not used for commercial purposes. reduction, and oxidation reactions of polyphosphorus units in neutral transition-metal complexes have been reported, ${ }^{[9]}$ while the reaction of main-group-element nucleophiles such as amides, phosphanides, hydrocarbyl anions, and N-heterocyclic carbenes (NHCs) is a versatile route to anionic complexes with functionalized polyphosphido ligands. ${ }^{[10]}$ In addition, Cummins and co-workers have very impressively demonstrated the synthetic potential of polyphosphido transition metalate anions for the synthesis of useful and novel P compounds. ${ }^{[6,11]}$

In comparison to the well-established neutral and anionic polyphosphorus compounds, the chemistry of polyphosphorus cations has only just begun to flourish a decade ago ${ }^{[12]}$ Recent studies clearly show the substantial influence of cationic substituents, for example, $\mathrm{NHCs}^{[13]}$ and phosphanes, ${ }^{[14]}$ on their stability and reactivity. ${ }^{[15]}$ However, the coordination chemistry of cationic polyphosphanes has scarcely been studied thus far. In contrast to a variety of neutral compounds I-IV ${ }^{[16-19]}$ (Figure 1) and anionic compounds V-VII, ${ }^{[10,19]}$ cationic polyphosphorus complexes with late transition metals (such as VIII) are extremely rare. ${ }^{[20]}$ In particular, the direct use of cationic polyphosphanes as ligands has not been investigated. This prompted us to study whether cationic polyphosphane complexes are accessible by reaction of

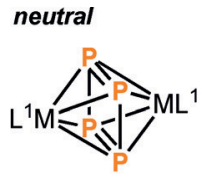

I (M: Fe, Co)

anionic

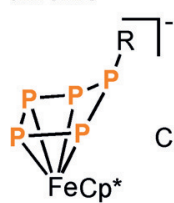

V<smiles>CCOC(=O)OC</smiles>

VIII

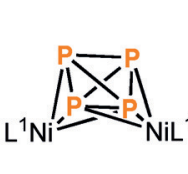

II<smiles>COC(=O)p1p(C)p(C)p(SC)p1C(=O)O</smiles>

III

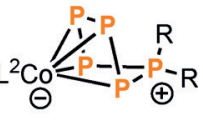

IV

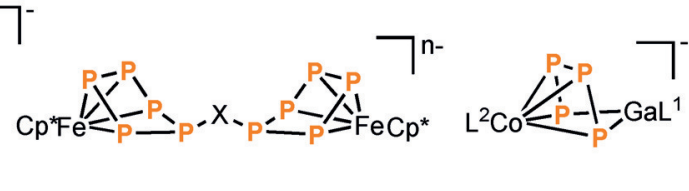

VII $N^{-}(n=3)$

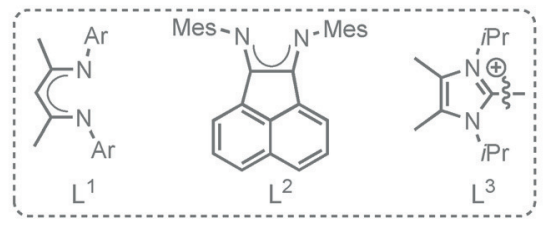

Figure 1. Selected late-transition-metal polyphosphorus complexes with $\mathrm{P}_{4}$ and $\mathrm{P}_{5}$ units. Mes $=2,4,6$-trimethylphenyl, $\mathrm{C} \mathrm{p}^{*}=$ pentamethylcyclopentadienyl. 


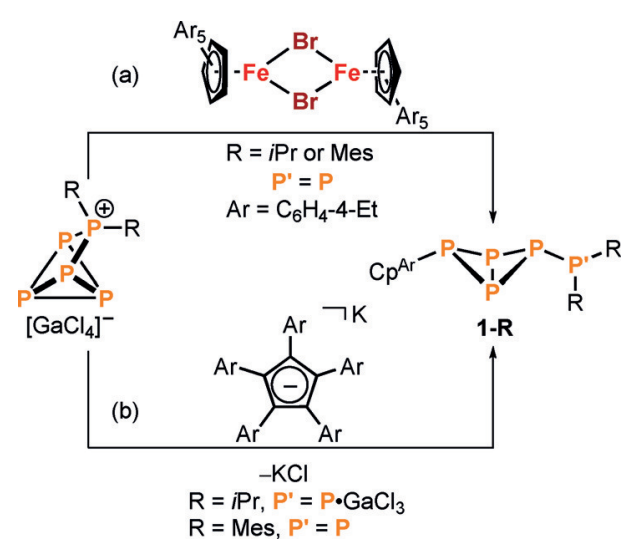

Scheme 1. Reaction of $\left[\mathrm{P}_{5} \mathrm{R}_{2}\right]\left[\mathrm{GaCl}_{4}\right]$ with a) $\left[C p^{\mathrm{Ar}} \mathrm{Fe}(\mu-\mathrm{Br})\right]_{2}$ and b) $\mathrm{K}\left[C \mathrm{P}^{\mathrm{Ar}}\right] \cdot \mathrm{Cp} \mathrm{Ar}^{\mathrm{Ar}}=\mathrm{C}_{5}\left(\mathrm{C}_{6} \mathrm{H}_{4}-4-\mathrm{Et}\right)_{5}$

suitable low-valent metal complexes with selected phosphorus cations.

$\left[\mathrm{P}_{5} \mathrm{R}_{2}\right]^{+}$cations (Scheme 1) seemed to be ideal candidates for such an investigation as they are readily accessible with a wide range of substituents by insertion of carbene-analogous phosphenium cations $\left[\mathrm{PR}_{2}\right]^{+}$into $\mathrm{P}-\mathrm{P}$ bonds of white phosphorus. ${ }^{[21,22]}$ Although their reactivity with elemental sulfur, selenium, and N-heterocyclic carbenes has been studied, ${ }^{[23,24]}$ their coordination behavior is completely unknown. Herein, we describe reactions of cyclopentadienyl iron, cobalt, and nickel complexes with such cations, which result in the formation of neutral bicyclo[1.1.0]pentaphosphanes $\mathbf{1 - R}(\mathbf{R}=i \operatorname{Pr}$ and Mes $)$ and cationic $\mathrm{P}_{5} \mathrm{R}_{2}$ complexes $\left[\left(\mathrm{Cp}^{\mathrm{Ar}} \mathrm{Co}\right)\left(\eta^{4}-\mathrm{P}_{5} \mathrm{R}_{2}\right)\right]^{+} \quad\left([\mathbf{2}-\mathbf{R}]^{+} ; \quad \mathrm{Cp}^{\mathrm{Ar}}=\right.$ $\mathrm{C}_{5}\left(\mathrm{C}_{6} \mathrm{H}_{4}-4-\mathrm{Et}\right)_{5}, \mathrm{R}=i \mathrm{Pr}$ and $\left.\mathrm{Cy}\right)$ and $\left[\left(\mathrm{Cp}^{\mathrm{Ar}} \mathrm{Ni}\right)_{2}\left(\eta^{3: 3}-\mathrm{P}_{5} \mathrm{R}_{2}\right)\right]$ $\left([\mathbf{3}-\mathbf{R}]^{+}\right)$. Unusual (pseudo)halogen and organo-substituted $\mathrm{P}_{5} \mathrm{R}_{2} \mathrm{X}(\mathrm{X}=\mathrm{Cl}, \mathrm{CN}$, and $\mathrm{Cy})$ frameworks are the result of post-functionalization reactions of $[\mathbf{2}-\mathbf{R}]^{+}$with $\left[\mathrm{Et}_{4} \mathrm{~N}\right][\mathrm{X}]$ $(\mathrm{X}=\mathrm{CN}$ and $\mathrm{Cl})$ and the Grignard reagent $\mathrm{CyMgCl}$.

As the cyclopentadienyl iron halide complex $\left[\mathrm{Cp}^{\mathrm{Ar}} \mathrm{Fe}(\mu-\right.$ $\mathrm{Br})]_{2}{ }_{2}^{[25]}$ had been successfully used for white phosphorus activation, ${ }^{[2]}$ it was selected as the starting point for our investigation. To our surprise, the reaction of this Fe complex with $\left[\mathrm{P}_{5} \mathrm{R}_{2}\right]\left[\mathrm{GaCl}_{4}\right]$ salts $(\mathrm{R}=i \mathrm{Pr}$ and Mes; Mes $=2,4,6$ $\mathrm{Me}_{3} \mathrm{C}_{6} \mathrm{H}_{2}$; Scheme $\left.1 \mathrm{a}\right)^{[23]}$ afforded remarkable, unsymmetrically substituted bicyclo[1.1.0]pentaphosphanes $\mathbf{1 - R}$ as the major product. The isopropyl-substituted pentaphosphane 1-iPr is formed in the reaction of $\left[\mathrm{Cp}^{\mathrm{Ar}} \mathrm{Fe}(\mu-\mathrm{Br})\right]_{2}$ and $\left[\mathrm{P}_{5} i \mathrm{Pr}_{2}\right]\left[\mathrm{GaCl}_{4}\right]$ and can be identified by an apparent $\mathrm{AMXY}_{2}$ spin system with multiplets at $\delta=-38.9,-87.0,-251.9$, and $-325.0 \mathrm{ppm}$ in the ${ }^{31} \mathrm{P}\left\{{ }^{1} \mathrm{H}\right\}$ NMR spectrum.

Unfortunately, 1-iPr rapidly decomposes in solution (even in apolar solvents such as $n$-hexane) into diphosphane $\mathrm{P}_{2} i \mathrm{Pr}_{4}$, white phosphorus, and further unknown products. Despite its low stability, yellow crystals of the gallium trichloride adduct 1-iPr. $\mathbf{G a C l}_{3}$ suitable for X-ray crystallography were obtained from the reaction of $\mathrm{K}\left[\mathrm{Cp}^{\mathrm{Ar}}\right]$ with $\left[\mathrm{P}_{5} i \mathrm{Pr}_{2}\right]\left[\mathrm{GaCl}_{4}\right]$, and the molecular structure is depicted in Figure $2 \mathrm{a}^{[27]}$ The core of the structure is an unsymmetrical, exo,exo-substituted $\mathrm{P}_{4}$ "butterfly" unit, showing a similar folding (P2‥P4 2.8047(10) $\AA$ ) as other exo,exo-substituted bicyclo[1.1.0]tetraphosphanes. ${ }^{[28]}$ As a consequence, the bridgehead a)

b)
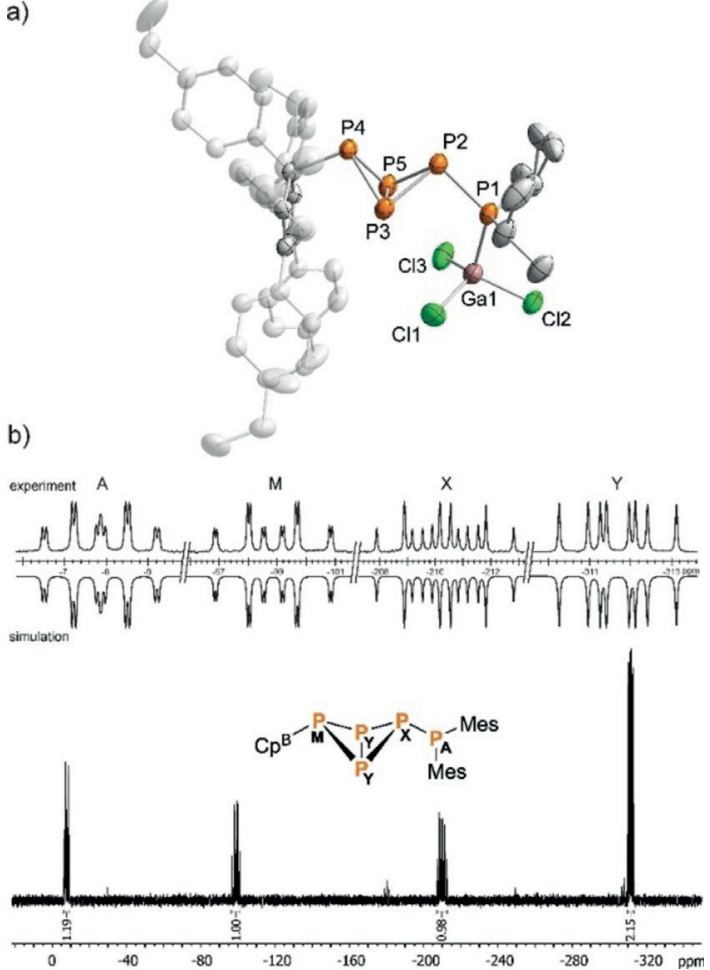

Figure 2. a) Solid-state molecular structure of compound $1-i \mathrm{Pr} \cdot \mathrm{GaCl}_{3}$ Ellipsoids set at $50 \%$ probability; $\mathrm{H}$ atoms are omitted for clarity. Selected bond lengths $[\AA]$ and angles $\left[{ }^{\circ}\right]$ : P1-P2 2.2104(11), P2-P3 2.2299(12), P2-P5 2.2219(11), P3-P4 2.2124(11), P4-P5 2.2218(11) P3-P5 2.1764(11), P2 ..P4 2.8047(10), P1-Gal 2.3857(10); P1-P2-P3 97.57(4), P1-P2-P5 102.19(5), P3-P2-P5 58.53(4), P2-P3-P4 78.31(4), P3-P4-P5 58.79(3), P2-P5-P4 78.28(4). b) ${ }^{31} \mathrm{P}\left\{{ }^{1} \mathrm{H}\right\}$ NMR spectrum of compound 1-Mes in $\mathrm{C}_{6} \mathrm{D}_{6}$ at room temperature. $\delta\left(\mathrm{P}_{\mathrm{A}}\right)=-7.9 \mathrm{ppm}$, $\delta\left(\mathrm{P}_{\mathrm{M}}\right)=-98.9 \mathrm{ppm}, \delta\left(\mathrm{P}_{\mathrm{X}}\right)=-210.4 \mathrm{ppm}$, and $\delta\left(\mathrm{P}_{\mathrm{Y}}\right)=-311.7 \mathrm{ppm}$; ${ }^{1} J_{A X}=-207.3 \mathrm{~Hz},{ }^{1} J_{X Y}=-162.1 \mathrm{~Hz},{ }^{1} J_{M Y}=-186.4 \mathrm{~Hz},{ }^{2} J_{A Y}=114.2 \mathrm{~Hz}$, ${ }^{2} J_{M X}=268.9 \mathrm{~Hz}$, and ${ }^{3} J_{A M}=15.4 \mathrm{~Hz}$

P3-P5 bond (2.1764(11) $\AA$ ) is shorter than the remaining $\mathrm{P}-\mathrm{P}$ bonds (2.2104(11)-2.2299(12) $\mathrm{A})$. The ${ }^{31} \mathrm{P}\left\{{ }^{1} \mathrm{H}\right\}$ NMR spectrum of 1-iPr. $\mathbf{G a C l}_{3}$ recorded in $\mathrm{C}_{6} \mathrm{D}_{6}$ (see the Supporting Information, Figure S8) is in agreement with the molecular structure $\left(\mathrm{AMXY}_{2}\right.$ spin system; $\delta=16.4,-107.3,-267.6$, and $-324.2 \mathrm{ppm})$. Note that the chemical shifts differ from those of 1-iPr obtained using the Fe complex because of the $\mathrm{GaCl}_{3}$ coordination (see above). As for 1-iPr, a detailed spectroscopic characterization of $\mathbf{1 - i} \mathbf{P r} \cdot \mathbf{G a C l}_{\mathbf{3}}$ was hampered by its rapid decomposition in solution. In contrast, however, the mesityl-substituted derivative 1-Mes can be synthesized by an analogous procedure using $\mathrm{K}\left[\mathrm{Cp}^{\mathrm{Ar}}\right]$ and $\left[\mathrm{P}_{5} \mathrm{Mes}_{2}\right]$ $\left[\mathrm{GaCl}_{4}\right]$ (Scheme $\left.1 \mathrm{~b}\right)$. 1-Mes is significantly more stable than 1-iPr (see Figure S87 for a ${ }^{31} \mathrm{P}\left\{{ }^{1} \mathrm{H}\right\}$ NMR monitoring study of its decomposition). 1-Mes can be isolated as a pure, greenishyellow solid in a moderate yield of $37 \%$. The ${ }^{31} \mathrm{P}\left\{{ }^{1} \mathrm{H}\right\}$ NMR spectrum of 1-Mes in $\mathrm{C}_{6} \mathrm{D}_{6}$ (Figure $2 \mathrm{~b}$ ) shows an $\mathrm{AMXY}_{2}$ spin system similar to those of related tetraphosphacyclo[1.1.0]butanes. ${ }^{[27-29]}$ An iterative fit of this spectrum revealed typical ${ }^{1} J_{\mathrm{PP}}$ coupling constants of $-207.3 \mathrm{~Hz},-162.1 \mathrm{~Hz}$, and $-186.4 \mathrm{~Hz}$ and $\mathrm{a}^{2} J_{\mathrm{PP}}$ coupling constant ${ }^{2} J_{\mathrm{MX}}$ of $268.9 \mathrm{~Hz}$. The latter, comparably very large ${ }^{2} J_{\mathrm{PP}}$ coupling constant indicates 
that the lone pairs of $\mathrm{P}_{\mathrm{M}}$ and $\mathrm{P}_{\mathrm{X}}$ are directed towards one another (see the Supporting Information for the full analysis of this spectrum). ${ }^{[28 i]}$

Reactions of $\left[\mathrm{P}_{5} \mathrm{R}_{2}\right]\left[\mathrm{GaCl}_{4}\right](\mathrm{R}=i \mathrm{Pr}$ and $\mathrm{Cy})$ with $\left[\mathrm{Cp}^{\mathrm{Ar}} \mathrm{M}\right.$ $(\mu-\mathrm{Br})]_{2} \quad(\mathrm{M}=\mathrm{Co}, \quad 1 \text { equiv; } \mathrm{M}=\mathrm{Ni}, \quad 2 \text { equiv })^{[25]}$ afford $\left[\left(\mathrm{Cp}^{\mathrm{Ar}} \mathrm{Co}\right)\left(\eta^{4}-\mathrm{P}_{5} \mathrm{R}_{2}\right)\right]\left[\mathrm{GaCl}_{4}\right] \quad\left(\mathbf{2}-\mathbf{R}\left[\mathrm{GaCl}_{4}\right]\right) \quad$ and $\left[\left(\mathrm{Cp}^{\mathrm{Ar}} \mathrm{Ni}\right)_{2}\left(\eta^{3: 3}-\mathrm{P}_{5} \mathrm{R}_{2}\right)\right]\left[\mathrm{GaCl}_{4}\right] \quad\left(\mathbf{3}-\mathbf{R}\left[\mathrm{GaCl}_{4}\right]\right)$ as dark-red or pink crystalline solids in low yields of $15-25 \%$. These reactions presumably involve a disproportionation of the metal(II) precursors to metal(I) and metal(III) compounds, which is induced by phosphorus ligand coordination, explaining the lower than expected yield. However, 2-R $\left[\mathrm{GaCl}_{4}\right]$ and $\mathbf{3 - R}\left[\mathrm{GaCl}_{4}\right]$ can be formed in good to high yield $(55-85 \%)$ by reacting $\left[\mathrm{P}_{5} \mathrm{R}_{2}\right]\left[\mathrm{GaCl}_{4}\right]$ salts directly with the cobalt(I) and nickel(I) compounds, that is, $\left[\mathrm{Cp}^{\mathrm{Ar}} \mathrm{Co}(\operatorname{cod})\right](1$ equiv, $\operatorname{cod}=$ 1,5-cyclooctadiene) ${ }^{[30]}$ and the transient " $\mathrm{Cp}^{\mathrm{Ar}} \mathrm{Ni}^{\mathrm{i}}$ " (2 equiv, generated from $\left[\mathrm{Cp}^{\mathrm{Ar}} \mathrm{Ni}(\mu-\mathrm{Br})\right]_{2}$ and $\mathrm{KC}_{8}$; Scheme 2$) .{ }^{[31]}$

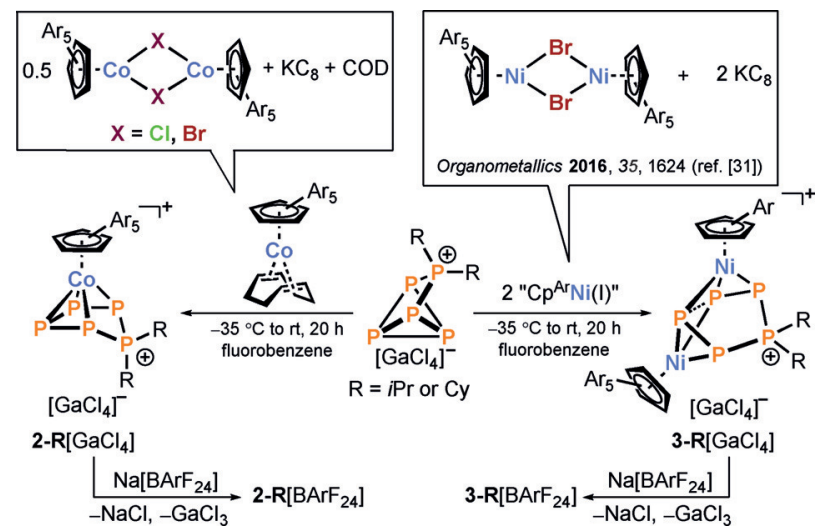

Scheme 2. Synthesis of 2-R $\left[\mathrm{GaCl}_{4}\right], 3-\mathrm{R}\left[\mathrm{GaCl}_{4}\right], 2-\mathrm{R}\left[\mathrm{BArF}_{24}\right]$, and 3-R$\left[\mathrm{BArF}_{24}\right] . \mathrm{R}=\mathrm{iPr}$ and $\mathrm{Cy}, \mathrm{BArF}_{24}=$ tetrakis[3,5-bis (trifluoromethyl) phenyl]borate, $\mathrm{Ar}=\mathrm{C}_{6} \mathrm{H}_{4}-4$-Et.

Single crystals of $\mathbf{2}-\mathbf{R}\left[\mathrm{GaCl}_{4}\right](\mathrm{R}=i \mathrm{Pr}$ and $\mathrm{Cy}$; dark red blocks) and 3-iPr$\left[\mathrm{GaCl}_{4}\right]$ (pink-violet blocks) were obtained from $\mathrm{THF} / n$-hexane at $-35^{\circ} \mathrm{C}$ and analyzed by $\mathrm{X}$-ray crystallography (Figure 3). The pentaphosphorus ligand is $\eta^{4}$-coordinated to the metal, resulting in an envelope conformation of the $\mathrm{P}_{5}$ fragment in $\mathbf{2}-\mathbf{R}\left[\mathrm{GaCl}_{4}\right]$. The arrangement of the $\mathrm{P} 2, \mathrm{P} 3, \mathrm{P} 4$, and $\mathrm{P} 5$ atoms is almost planar with $\mathrm{P}-\mathrm{P}$ bonds that are slightly shorter than typical single bonds. For 2-R $\left[\mathrm{GaCl}_{4}\right]$, the $\mathrm{P}-\mathrm{P}$ bonds of the tetracoordinate $\mathrm{P}$ atom (P1) are approximately $0.025 \AA$ longer than those between the coordinated $\mathrm{P}$ atoms. 3-iPr$\left[\mathrm{GaCl}_{4}\right]$ has an unprecedented molecular structure where two " $\mathrm{Cp}^{\mathrm{Ar}} \mathrm{Ni}$ " fragments are $\eta^{3}$ coordinated to a cyclo- $\mathrm{P}_{5} i \mathrm{Pr}_{2}$ ring. The $\mathrm{P}_{5}$ unit is in a twist conformation as evidenced by the dihedral angle between the $\mathrm{P} 2-\mathrm{P} 3-\mathrm{P} 4$ and P3-P4-P5 planes of $-67.9^{\circ}$. This ligand features one unusually long $\mathrm{P}-\mathrm{P}$ bond (P3-P4 2.5002(16) $\AA$ ) due to the coordination of each $\mathrm{P}$ atom to two Ni centers, while the remaining $\mathrm{P}-\mathrm{P}$ distances (P1-P2 2.1835(17) $\AA$, P1-P5 2.1859-

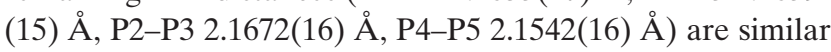
to those of $\mathbf{2}-\mathbf{R}\left[\mathrm{GaCl}_{4}\right]$.

${ }^{31} \mathrm{P}\left\{{ }^{1} \mathrm{H}\right\}$ NMR spectra of $\mathbf{2}-\mathbf{R}\left[\mathrm{GaCl}_{4}\right]$ in $\mathrm{C}_{6} \mathrm{D}_{6}$ show three multiplets of an $\mathrm{AMM}^{\prime} \mathrm{XX}^{\prime}$ spin system in agreement with a)

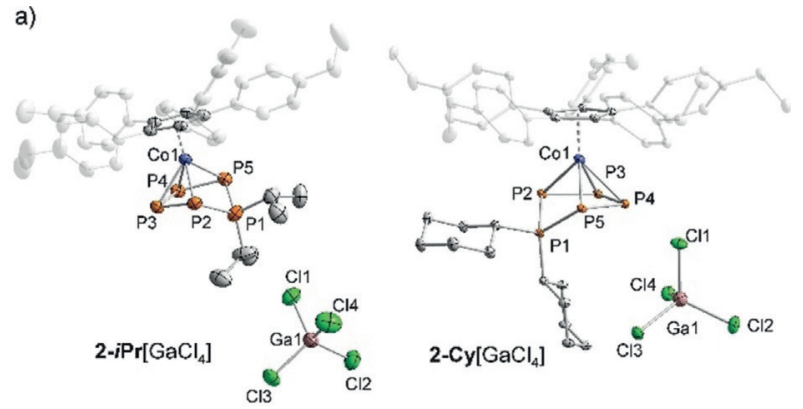

b)

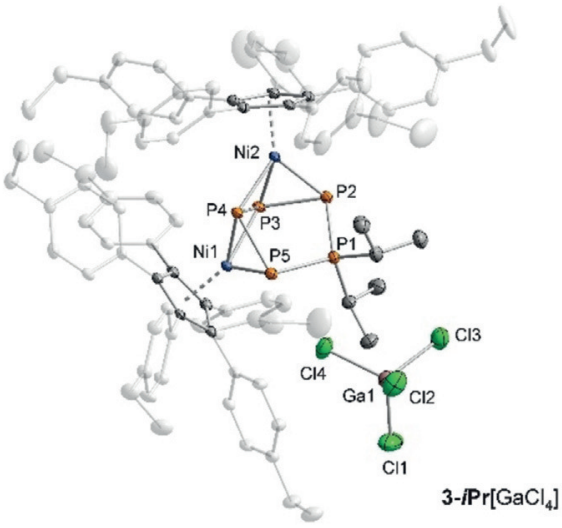

Figure 3. Solid-state molecular structures of complexes $2-\mathrm{R}\left[\mathrm{GaCl}_{4}\right]$ $(\mathrm{R}=i \operatorname{Pr}$ and $\mathrm{Cy})$ (a) and 3-iPr $\left[\mathrm{GaCl}_{4}\right]$ (b). Ellipsoids set at $50 \%$ probability; $\mathrm{H}$ atoms, solvent molecules in $2-\mathrm{Cy}\left[\mathrm{GaCl}_{4}\right]$, and disorder in the ethyl groups and the tetrachlorogallate anion of $2-i \operatorname{Pr}\left[\mathrm{GaCl}_{4}\right]$ are omitted for clarity. The crystal of 2-iPr $\left[\mathrm{GaCl}_{4}\right]$ contained a second crystallographically independent molecule with very similar structural parameters; only one of these molecules is shown. Selected bond lengths $[\AA \AA]$ and angles $\left[^{\circ}\right]$ for $2-i \operatorname{Pr}\left[\mathrm{GaCl}_{4}\right]$ : P1-P2 2.1543(12), 2.1592(12); P2-P3 2.1382(12), 2.1362(12); P3-P4 2.1371 (12), 2.1370(12); P4-P5 2.1267(12), 2.1377(12); P1-P5 2.1449(12), 2.1558(11); Col-P2 2.3227(9), 2.3316(9); Col-P3 2.3219(10), 2.3249(9); Col-P4 2.3396(9), 2.3368(9); Co1-P5 2.3269(9), 2.3225(10); P2-P1-P5 97.09(5), 97.15(4), P1-P2-P3 99.87(5), 101.08(5); P2-P3-P4 105.21(5), 105.36(5); P3-P4-P5 104.26(5), 104.43(5); P4-P5-P1 100.91 (5), 101.50(4); 2-Cy$\left[\mathrm{GaCl}_{4}\right]$ : P1-P2 2.1633(6), P2-P3 2.1361 (7), P3-P4 2.1414(7), P4-P5 2.1327(7), P1-P5 2.1658(6), Co1-P2 2.3294(5), Co1-P3 2.3213(6), Co1-P4 2.3443(6), Co1-P5 2.3376(5); P2-P1-P5 96.58(2), P1-P2-P3 101.01 (3), P2-P3-P4 105.12(3), P3-P4-P5 104.48(3), P4-P5-P1 101.27(3); 3-iPr[GaCl $]$ : P1-P2 2.1835(17), P2-P3 2.1672(16), P3-P4 2.5002(16), P4-P5 2.1542(16), P1-P5 2.1859(15), Ni1-P3 2.2388(12), Ni1-P4 2.2519(13), Ni1-P5 2.2547(15), Ni2-P2 2.2473(13), Ni2-P3 2.2671 (13), Ni2-P4 2.2202(12); P2-P1-P5 108.73(6), P1-P2-P3 97.38(6), P2-P3-P4 96.11 (6), P3-P4-P5 92.73(6), P4-P5-P1 100.25(6).

a persistent, symmetrical $\mathrm{P}_{5} \mathrm{R}_{2}$ ligand. The spectral parameters were determined by an iterative fitting procedure in each case (see the Supporting Information for details). For 2-R $\left[\mathrm{GaCl}_{4}\right]$, the data are similar to those of related $\alpha$-diimine complexes (IV in Figure 1). ${ }^{31} \mathrm{P}\left\{{ }^{1} \mathrm{H}\right\} \quad$ NMR spectra of 3-R $\left[\mathrm{GaCl}_{4}\right]$ display three multiplets of an $\mathrm{AA}^{\prime} \mathrm{MXX}^{\prime}$ spin system. The very small magnitude of the ${ }^{1} J_{\mathrm{AA}^{\prime}}$ coupling constants in 3-R $\left[\mathrm{GaCl}_{4}\right]\left({ }^{1} J_{\mathrm{AA}^{\prime}}=-7.5 \mathrm{~Hz}\right.$ for 3-iPr $\left[\mathrm{GaCl}_{4}\right]$ and ${ }^{1} J_{\mathrm{AA}^{\prime}}=-18.7 \mathrm{~Hz}$ for $\left.\mathbf{3 - C y}\left[\mathrm{GaCl}_{4}\right]\right)$ is noteworthy. This observation agrees well with a weak $\mathrm{P}-\mathrm{P}$ bond in the $\beta$-position with respect the phosphonium center (see the discussion of the $\mathrm{X}$-ray structure above), and the remaining ${ }^{1} J_{\mathrm{PP}}$ couplings 
are unexceptional; for 3-iPr$\left[\mathrm{GaCl}_{4}\right]:{ }^{1} J_{\mathrm{MX}}={ }^{1} J_{\mathrm{MX}^{\prime}}=-420.4 \mathrm{~Hz}$ and ${ }^{1} J_{\mathrm{AX}}={ }^{1} J_{\mathrm{A}^{\prime} \mathrm{X}^{\prime}}=-346.2 \mathrm{~Hz}$. The fluxional behavior of the $\mathrm{Ni}$ complexes is another notable aspect, which was observed by variable temperature (VT) ${ }^{31} \mathrm{P}\left\{{ }^{1} \mathrm{H}\right\}$ NMR studies on 3-R$\left[\mathrm{GaCl}_{4}\right]$ in $\left[\mathrm{D}_{8}\right] \mathrm{THF}$ (Figure 4). A symmetrical AA'MXX'

a)

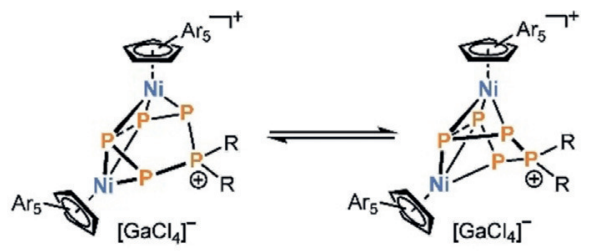

b)

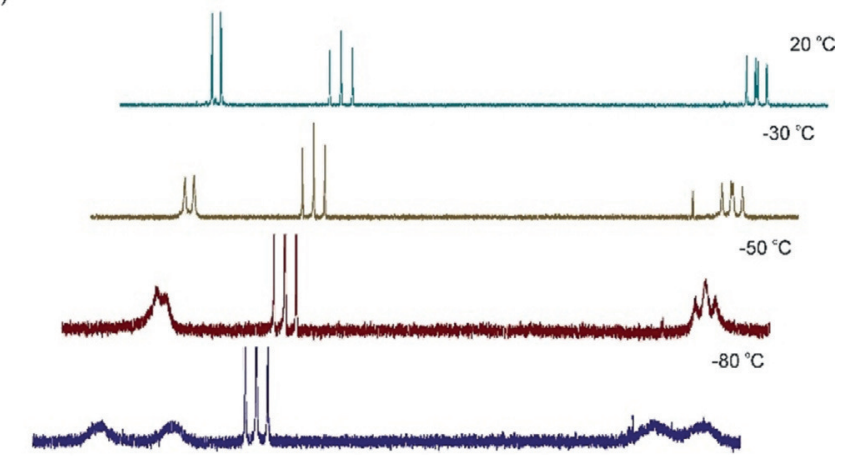

$-100^{\circ} \mathrm{C}$

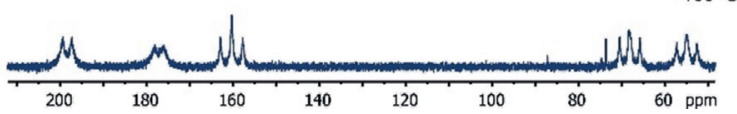

Figure 4. a) Dynamic behavior of $3-\mathrm{R}\left[\mathrm{GaCl}_{4}\right]$ at room temperature; $\mathrm{Ar}=\mathrm{C}_{6} \mathrm{H}_{4}$-4-Et. b) $\mathrm{VT}{ }^{31} \mathrm{P}\left\{{ }^{1} \mathrm{H}\right\}$ NMR spectra of complex 3-iPr$\left[\mathrm{GaCl}_{4}\right]$ in $\left[D_{8}\right]$ THF.

spin system is observed at room temperature, which decoalesces into an AEMXY spin system below $-80^{\circ} \mathrm{C}$ (see Figure $4 \mathrm{~b}$ and Figure S88). The prevalence of an intramolecular exchange process as shown in Figure 4 a was additionally confirmed by a ${ }^{31} \mathrm{P}-{ }^{31} \mathrm{P}$ EXSY experiment on $\mathbf{3}-\mathbf{C y}\left[\mathrm{GaCl}_{4}\right]$ in $\left[\mathrm{D}_{8}\right] \mathrm{THF}$ at $-80^{\circ} \mathrm{C}$, which shows correlation peaks at $\delta=204$ and $179 \mathrm{ppm}$ (Figure S89). The NMR spectroscopic data of 2-R $\left[\mathrm{GaCl}_{4}\right]$ and $\mathbf{3}-\mathbf{R}\left[\mathrm{GaCl}_{4}\right]$ thus clearly indicate that the coordination mode of the cyclo- $\mathrm{P}_{5} \mathrm{R}_{2}$ ligand observed in the solid-state structures is retained in solution.

Aiming at the further functionalization of the $\mathrm{P}_{5} \mathrm{R}_{2}$ ligands, reactions of $[\mathbf{2}-\mathbf{R}]^{+}$and $[\mathbf{3}-\mathbf{R}]^{+}$with nucleophilic anions were examined. In order to facilitate such studies, the $\left[\mathrm{GaCl}_{4}\right]^{-}$counteranion was first replaced by reacting 2-R $\left[\mathrm{GaCl}_{4}\right]$ and 3-R $\left[\mathrm{GaCl}_{4}\right]$ with $\mathrm{Na}\left(\mathrm{BArF}_{24}\right)$ (Scheme 2). The desired salts $\mathbf{2}-\mathbf{R}\left[\mathrm{BArF}_{24}\right]$ and $\mathbf{3}-\mathbf{R}\left[\mathrm{BArF}_{24}\right]$ can be isolated as pure compounds in moderate to high yields (47$79 \%)$; their cations show nearly identical structural and spectroscopic data as the tetrachlorogallate salts (see the Supporting Information for details). Initial reactivity tests revealed that chloro and cyano substituents are readily incorporated into the cobalt complexes, while the dinickel species 3-R $\left[\mathrm{BArF}_{24}\right]$ are unreactive. Treatment of 2-R$\left[\mathrm{BArF}_{24}\right]$ with $\left[\mathrm{Et}_{4} \mathrm{~N}\right] \mathrm{X}$ ( 1 equiv, $\mathrm{X}=\mathrm{CN}$ and $\mathrm{Cl}$ ) as shown in Scheme 3 selectively gives $\left[\mathrm{Cp}^{\mathrm{Ar}} \mathrm{Co}\left\{\eta^{4}-\mathrm{P}_{5} \mathrm{R}_{2}(\mathrm{X})\right\}\right]$ (2-X-R,

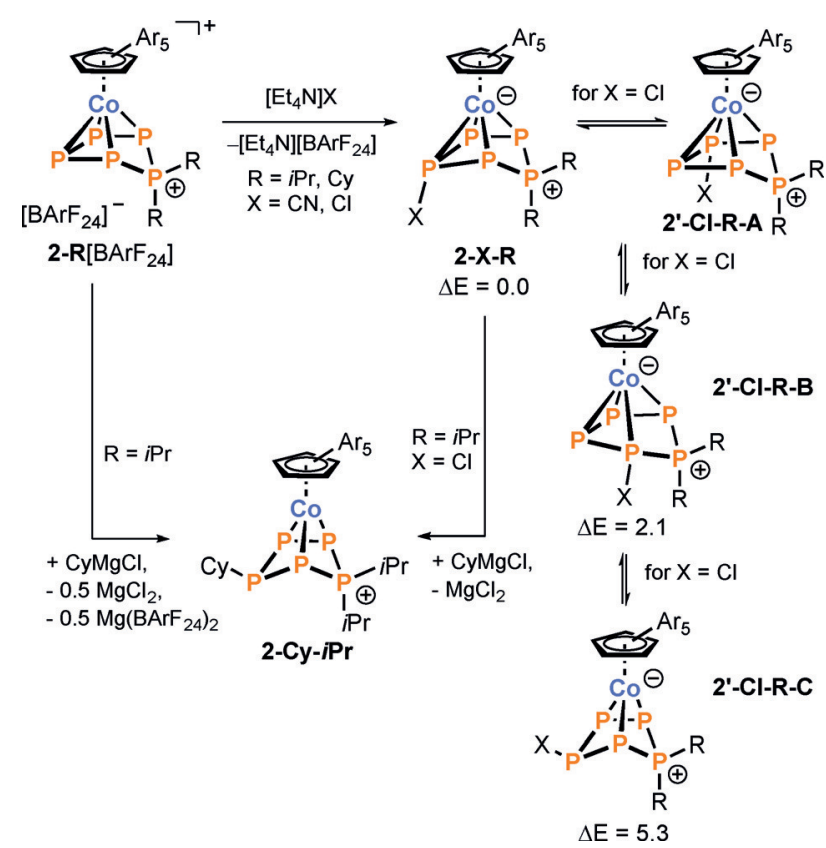

Scheme 3. Functionalization of the cyclo- $\mathrm{P}_{5} \mathrm{R}_{2}$ backbone of $2-\mathrm{R}\left[\mathrm{BArF} \mathrm{F}_{24}\right]$; $\mathrm{Ar}=\mathrm{C}_{6} \mathrm{H}_{4}-4$-Et. Relative electronic energies $\left(\Delta E\right.$ in $\left.\mathrm{kcal} \mathrm{mol}^{-1}\right)$ are given for the calculated isomers $\mathbf{B}$ and $\mathbf{C}$ of the truncated model complex $\left[\mathrm{Cp}^{\mathrm{Ph}} \mathrm{Co}\left\{\eta^{4}-\mathrm{P}_{5} i \mathrm{Pr}_{2}(\mathrm{X})\right\}\right] \mathbf{2}^{\prime}$-X-iPr-A (see Table S17 for thermal enthalpies and free enthalpies).

$\mathrm{X}=\mathrm{CN}$ and $\mathrm{Cl}, \mathrm{R}=i \mathrm{Pr}$ and $\mathrm{Cy}$; Figure $5 \mathrm{a}$ ) according to ${ }^{31} \mathrm{P}$ NMR spectroscopy. The products can be isolated as pure, dark-red, crystalline solids in $65-75 \%$ yield. Single-crystal Xray diffraction analysis on red plates obtained from $\mathrm{Et}_{2} \mathrm{O} / n$ pentane show that the (pseudo)halogen substituent is connected to the $\beta$-position with respect to the phosphonium center of the pentaphosphorus ligand in all cases. The molecular structures of $\mathbf{2 - C N}-\mathbf{i} \mathbf{P r}$ and $\mathbf{2 - C l}-\mathbf{i} \mathbf{P r}$ are shown in Figure $5 \mathrm{a}$. The $\mathrm{Co}-\mathrm{P}$ bond of the cyano- or chloro-substituted phosphorus atom (2-CN-iPr: Co1-P3 2.8558(13) ^; 2-Cl-iPr: Co1-P3 2.7301(17) $\AA$ ) is elongated by $0.4 \AA$ to $0.5 \AA$ compared to the remaining $\mathrm{Co}-\mathrm{P}$ bonds. As a result, the substituted $\mathrm{P}$ atoms $\mathrm{P} 1$ and $\mathrm{P} 3$ are below the P2-P4-P5 plane. The dihedral angle P2-P3-P4-P5 is 23.20(8) ${ }^{\circ}$ in 2-CN-iPr and $16.2(1)^{\circ}$ in 2-Cl-iPr. For 2-CN-iPr, the P3-C46 and C46-N1 bond lengths of 1.831(4) $\AA$ and 1.141(5) $\AA$ indicate the $\mathrm{P}-\mathrm{C}$ single and $\mathrm{C} \equiv \mathrm{N}$ triple bonds. ${ }^{[32]}$ The $\mathrm{P} 4-\mathrm{Cl} 1$ bond $(2.205(2) \AA$ ) in 2-Cl-iPr is $0.16 \AA$ longer than in typical alkyl or aryl chlorophosphanes. ${ }^{[22 \mathrm{c}]}$ The $\mathrm{P}-\mathrm{P}$ bond lengths in the cyclo- $\mathrm{P}_{5} \mathrm{R}_{2}$ ring are in a close range (2.1502(15)-2.1804(17) $\AA$ for 2-CN$\boldsymbol{i P r}$ and 2.142(2)-2.1691(18) $\AA$ for 2-Cl-iPr), showing that the $\mathrm{P}_{5}$ ring bonds are intact.

The ${ }^{31} \mathrm{P}\left\{{ }^{1} \mathrm{H}\right\}$ NMR spectrum of $\mathbf{2 - C N}-\mathbf{i} \mathbf{P r}$ in $\mathrm{C}_{6} \mathrm{D}_{6}$ shows five multiplets of an AEMXY spin system at room temperature, which is in agreement with the unsymmetrical solidstate structure (see Figures S62 and S63). The ${ }^{1} J_{\mathrm{PP}}$ coupling constants obtained by iterative fitting $(-324.7 \mathrm{~Hz}$ to $-400.2 \mathrm{~Hz}$ ) are typical for $\mathrm{P}-\mathrm{P}$ single bonds, while the ${ }^{2} J_{\mathrm{PP}}$ coupling constants $\left({ }^{2} J_{\mathrm{AE}}=-3.9 \mathrm{~Hz},{ }^{2} J_{\mathrm{AM}}=-7.7 \mathrm{~Hz},{ }^{2} J_{\mathrm{MY}}=\right.$ $\left.80.3 \mathrm{~Hz},{ }^{2} J_{\mathrm{EX}}=50.0 \mathrm{~Hz},{ }^{2} J_{\mathrm{XY}}=-6.4 \mathrm{~Hz}\right)$ span a large range. Small ${ }^{2} J_{\mathrm{PP}}$ couplings such as ${ }^{2} J_{\mathrm{AE}}$ and ${ }^{2} J_{\mathrm{AM}}$ are typical for tetracoordinate $\mathrm{P}$ atoms. ${ }^{[19-23]}$ 
b)
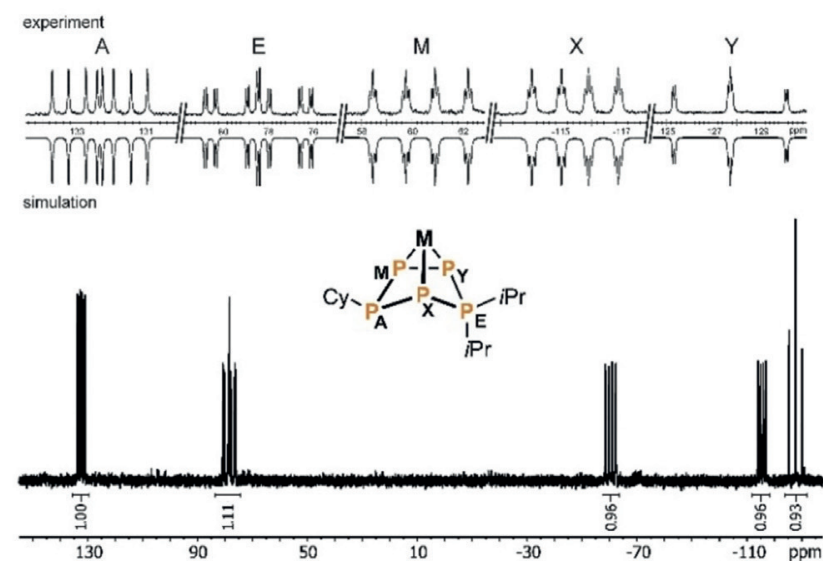

Figure 5. a) Solid-state molecular structures of $2-\mathrm{CN}-i \mathrm{Pr}$ (top left), $2-\mathrm{Cl}$ iPr (top right), and 2-Cy-iPr (bottom). Ellipsoids set at 50\% (2-CN-iPr and 2-Cy-iPr) and 30\% (2-Cl-iPr) probability; $\mathrm{H}$ atoms, solvent molecules $\left(\mathrm{Et}_{2} \mathrm{O}\right.$ and $n$-pentane in 2-CN-iPr), and disorder of the ethyl groups of $\mathrm{CP}^{\mathrm{Ar}}$ (in 2-CN-iPr and 2-Cy-iPr) and cyclo- $\mathrm{P}_{5} \mathrm{CNiPr}_{2}$ (in 2-CNiPr) are omitted for clarity. Selected bond lengths $[\AA]$ and angles $\left[{ }^{\circ}\right]$ for 2-CN-iPr: P1-P2 2.1615(9), P2-P3 2.1730(13), P3-P4 2.1804(17), P4P5 2.1502(15), P1-P5 2.1541(10), Co1-P2 2.3173(7), Col-P3 2.8558(13), Col-P4 2.3072(13), Col-P5 2.3031 (7), P3-C46 1.831(4), C46-N1 1.141(5); P2-P1-P5 97.31(4), P1-P2-P3 99.68(4), P2-P3-P4 96.15(6), P3P4-P5 109.36(6), P4-P5-P1 100.91(5), P2-P3-C46 110.87(14), P4-P3-C46 109.29(13), P3-C46-N1 173.3(4); for 2-Cl-iPr: P1-P2 2.1691 (18), P2-P3 2.142(2), P3-P4 2.1510(19), P4-P5 2.150(2), P1-P5 2.1458(18), Co1P2 2.3227(14), Col-P3 2.7301 (17), Co1-P4 2.3214(16), Col-P5 2.2987. (15), P4-Cl1 2.205(2); P2-P1-P5 97.11 (7), P1-P2-P3 100.62(8), P2-P3-P4 98.77(8), P3-P4-P5 109.08(8), P4-P5-P1 100.51 (7), P2-P3-Cl1 110.07(9), P4-P3-Cl1 110.93 (9); for 2-Cy-iPr: P1-P2 2.1506(14), P2-P3 2.2327(16), P3-P4 2.2185(15), P4-P5 2.1493(15), P1-P5 2.1697(15), Co1-P2 2.2831(12), Col-P4 2.2648(11), Col-P5 2.3152(11); P2-P1-P5 95.55(5), P1-P2-P3 87.95(6), P2-P3-P4 86.30(5), P3-P4-P5 102.87(6), P4-P5-P1 99.77(6). b) ${ }^{31} \mathrm{P}\left\{{ }^{1} \mathrm{H}\right\}$ NMR spectrum of complex 2-Cy-iPr in $\mathrm{C}_{6} \mathrm{D}_{6}$ at room temperature; $\delta\left(\mathrm{P}_{\mathrm{A}}\right)=132.3 \mathrm{ppm}, \delta\left(\mathrm{P}_{\mathrm{E}}\right)=78.4 \mathrm{ppm}, \delta\left(\mathrm{P}_{\mathrm{M}}\right)=$ $-60.4 \mathrm{ppm}, \delta\left(\mathrm{P}_{\mathrm{x}}\right)=-115.5$, and $\delta\left(\mathrm{P}_{\mathrm{Y}}\right)=-127.7 \mathrm{ppm}$;

${ }^{1} J_{A M}=-211.2 \mathrm{~Hz},{ }^{1} J_{M Y}=-396.4 \mathrm{~Hz},{ }^{1} J_{\mathrm{EY}}=-382.8 \mathrm{~Hz},{ }^{1} J_{\mathrm{EX}}=-302.7 \mathrm{~Hz}$, ${ }^{1} J_{\mathrm{AX}}=-158.5 \mathrm{~Hz},{ }^{2} J_{\mathrm{AY}}=-2.6 \mathrm{~Hz},{ }^{2} J_{\mathrm{AE}}=76.7 \mathrm{~Hz},{ }^{2} J_{\mathrm{EM}}=19.4 \mathrm{~Hz}$, ${ }^{2} J_{\mathrm{MX}}=19.5 \mathrm{~Hz}$, and ${ }^{2} \mathrm{~J}_{\mathrm{XY}}=16.3 \mathrm{~Hz}$.

Unlike 2-CN-R, the ${ }^{31} \mathrm{P}\left\{{ }^{1} \mathrm{H}\right\}$ NMR spectrum of 2-Cl-R shows an $\mathrm{AMM}^{\prime} \mathrm{XX}^{\prime}$ spin system with broadened $\mathrm{MM}^{\prime}$ and $\mathrm{XX}^{\prime}$ multiplets at room temperature. Variable-temperature ${ }^{31} \mathrm{P}\left\{{ }^{1} \mathrm{H}\right\}$ NMR measurements show that the signals decoalesce upon cooling, and an AEMXY spin system appears below $-50^{\circ} \mathrm{C}$ in $\left[\mathrm{D}_{8}\right] \mathrm{THF}$ (Figures $\mathrm{S} 92$ and S93). This observation is postulated to be due to an exchange of the chlorine atoms between the $\mathrm{P} 3$ and $\mathrm{P} 4$ atoms of the cyclo- $\mathrm{P}_{5} \mathrm{R}_{2}$ ring (Scheme 3). Indeed, DFT calculations on the truncated model complex $\left[\mathrm{Cp}^{\mathrm{Ph}} \mathrm{Co}\left\{\eta^{4}-\mathrm{P}_{5} i \mathrm{Pr}_{2}(\mathrm{X})\right\}\right] \quad \boldsymbol{2}^{\prime}-\mathbf{X}-\boldsymbol{i P r}(\mathrm{X}=\mathrm{Cl}$ and $\mathrm{Cy}$; $\mathrm{Cp}^{\mathrm{Ph}}=\mathrm{C}_{5}\left(\mathrm{C}_{6} \mathrm{H}_{5}\right)_{5}, \mathrm{PBE} / \mathrm{def} 2-\mathrm{TZVP}$ level, see the Supporting Information for further details) gave several low-energy isomers, which likely form an equilibrium in solution (see Scheme 3). Isomer $\mathbf{2}^{\prime}$-Cl-iPr-A, which corresponds to the crystallographically observed species, has the lowest energy compared to the exo-isomer $\mathbf{2}^{\prime}$-Cl-iPr-C $\left(+5.3 \mathrm{kcalmol}^{-1}\right)$ and the P2-substituted derivative $\mathbf{2}^{\prime}$-Cl-iPr-B (+2.1 kcal $\mathrm{mol}^{-1}$; see Scheme 3 and the Supporting Information for details). The experimental ${ }^{31} \mathrm{P}\left\{{ }^{1} \mathrm{H}\right\}$ NMR spectrum of 2-Cl-iPr (Figure S92) shows a second isomer (AEMXY spin system) below $-70^{\circ} \mathrm{C}$, which could correspond to 2-Cl-iPr-B or 2-Cl-iPr-C. ${ }^{[33]}$

Initial attempts toward the organofunctionalization of 2-R[BArF 24 with $\mathrm{CyMgCl}$ led to a product mixture (Figure S83) with $\left[\mathrm{Cp}^{\mathrm{Ar}} \mathrm{Co}\left\{\eta^{3}-\mathrm{P}_{5} i \mathrm{Pr}_{2}(\mathrm{Cy})\right\}\right](\mathbf{2}-\mathbf{C y}-\boldsymbol{i P r})$ as the major species, showing an AEMXY spin system. 2-Cy-iPr is formed cleanly in the reaction of $\mathbf{2 - C l}-\mathbf{i P r}$ with $\mathrm{CyMgCl}$ (Scheme 3), from which it can be isolated as a dark-red, crystalline solid in $68 \%$ yield. The molecular structure determined by singlecrystal X-ray diffraction is shown in Figure 5 a. Different from 2-X-iPr $(\mathrm{X}=\mathrm{CN}$ and $\mathrm{Cl}$, also shown in Figure $5 \mathrm{a})$, an exo configuration of the Cy substituent is observed, that is, the cyclohexyl substituent points towards the cyclopentadienyl ring. The pentaphosphorus ligand is clearly $\eta^{3}$-coordinated

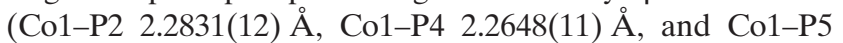
$2.3152(11) \AA)$ and shows a boat conformation as a result. The $\mathrm{P}-\mathrm{P}$ bonds of the cyclohexyl-substituted P atom P3 (P2-P3

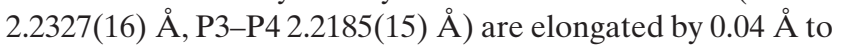
$0.09 \AA$ compared to the chloro- and cyano-substituted $\mathrm{P}$ atoms in 2-X-iPr $(\mathrm{X}=\mathrm{CN}$ and $\mathrm{Cl})$. The AEMXY spin system of $\mathbf{2 - C y - i P r}$ was successfully simulated by iterative fitting (Figure 5b) and compared to $\mathbf{2}-\mathbf{C N}-\mathbf{R}$, revealing significant differences concerning the ${ }^{1} J_{\mathrm{PP}}$ and ${ }^{2} J_{\mathrm{PP}}$ coupling constants. For example, the magnitudes of ${ }^{1} J_{\mathrm{AM}}=-211.2 \mathrm{~Hz}$ and ${ }^{1} J_{\mathrm{AX}}=$ $-158.5 \mathrm{~Hz}$ are much smaller than in the cyano-substituted compounds (see above). Such changes likely arise from the different conformations of the $\mathrm{P}_{5}$ ring. DFT calculations on the model complex $\mathbf{2}^{\prime}-\mathbf{C y}-\boldsymbol{i} \mathbf{P r}$, where the ethyl groups on the cyclopentadienyl ligand were replaced by hydrogen atoms, suggest that the exo isomer is $8.6 \mathrm{kcal} \mathrm{mol}^{-1}$ more stable than the endo-configured product. DFT calculations of NMR chemical shielding (Table S21,) for the exo isomer suggest the assignment shown in Figure $5 \mathrm{~b}$; the calculated chemical shifts are in fairly good agreement with the experimentally observed values.

It seems important to note that reactions of $\left[\mathrm{P}_{5} \mathrm{Mes}_{2}\right]$ $\left[\mathrm{BArF}_{24}\right]$ with $\left[\mathrm{Et}_{4} \mathrm{~N}\right] \mathrm{X}(\mathrm{X}=\mathrm{Cl}$ and $\mathrm{CN})$ and $\mathrm{CyMgCl}$ failed to give functionalization products (see the Supporting Information for details). This observation illustrates that the transition-metal coordination is of key importance here to achieve the functionalization of the $\mathrm{P}_{5} \mathrm{R}_{2}$ scaffold.

In summary, we have comprehensively studied the hitherto unknown coordination behavior of cationic poly- 
phosphorus compounds of type $\mathrm{P}_{5} \mathrm{R}_{2}{ }^{+}$. These studies have resulted in unusual cationic complexes $\mathbf{2}-\mathbf{R}\left[\mathrm{GaCl}_{4}\right]$ and 3-R $\left[\mathrm{GaCl}_{4}\right](\mathrm{R}=i \mathrm{Pr}$ and $\mathrm{Cy})$, while the first neutral bicyclo[1.1.0]pentaphosphanes (1-R) were obtained by treatment of $\left[\mathrm{P}_{5} \mathrm{R}_{2}\right]\left[\mathrm{GaCl}_{4}\right]\left(\mathrm{R}=i \mathrm{Pr}\right.$ and Mes) with $\left[\mathrm{Cp}^{\mathrm{Ar}} \mathrm{Fe}(\mu-\mathrm{Br})\right]_{2}$, or, more conveniently, with $\mathrm{K}\left[\mathrm{Cp}^{\mathrm{Ar}}\right]$. The functionalization of the polyphosphorus ligands in the $[\mathbf{2}-\mathbf{R}]^{+}$cations is straightforward after anion exchange of $\left[\mathrm{GaCl}_{4}\right]^{-}$for $\left[\mathrm{BArF}_{24}\right]^{-}$, and the resulting mixed substituted complexes $\mathbf{2 - X}-\mathbf{R}(\mathrm{X}=\mathrm{CN}$ and $\mathrm{Cl}$ ) can be further modified as demonstrated by the synthesis of 2-Cy-iPr from 2-Cl-iPr. The "functionalization by complexation" approach thus potentially enables the preparation of hitherto inaccessible and multiply substituted polyphosphorus scaffolds in the coordination sphere of transitionmetal cations. This strategy is complementary to previously reported methods for the synthesis of functionalized polyphosphorus complexes, ${ }^{[9,10 c, 11,19]}$ and further extensions should give access to a broad range of novel $\mathrm{P}_{n}$ frameworks.

\section{Acknowledgements}

We thank Dr. Uttam Chakraborty (University of Hamburg), M. Sc. Christian Hoidn (University of Regensburg), and Dr. Michael Bodensteiner (University of Regensburg) for assistance and Dr. John Kelly (University of Regensburg) for proofreading the manuscript. Funding by the Deutsche Forschungsgemeinschaft (WE4621/3-1 and WO1496/7-1) and the European Research Council (CoG 772299) is gratefully acknowledged.

\section{Conflict of interest}

The authors declare no conflict of interest.

Keywords: cobalt · coordination compounds - nickel · $P$ ligands · phosphorus

How to cite: Angew. Chem. Int. Ed. 2019, 58, 18584-18590 Angew. Chem. 2019, 131, 18757-18763

[1] N. Wiberg, E. Wiberg, A. F. Hollemann, Lehrbuch der Anorganischen Chemie, 102. Auflage, de Gruyter, Berlin, 2007, p. 758.

[2] a) A. H. Cowley, Chem. Rev. 1965, 65, 617; b) M. Scheer, G. B. Basázs, A. Seitz, Chem. Soc. Rev. 2010, 110, 4236; c) J. J. Weigand, N. Burford in Comprehensive Inorganic Chemistry II, Vol. 1 (Eds.: J. Reedijk, K. Poeppelmeier), Oxford, Elsevier, 2013, pp. 119-149.

[3] a) M. Baudler, Angew. Chem. Int. Ed. Engl. 1965, 4, 443; Angew. Chem. 1965, 77, 433; b) M. Baudler, Angew. Chem. Int. Ed. Engl. 1982, 21, 492; Angew. Chem. 1982, 94, 520; c) M. Baudler, Angew. Chem. Int. Ed. Engl. 1987, 26, 419; Angew. Chem. 1987, 99, 429; d) M. Baudler, K. Glinka, Chem. Rev. 1993, 93, 1623; e) M. Baudler, K. Glinka, Chem. Rev. 1994, 94, 1273.

[4] H. G. von Schnering, W. Hoenle, Chem. Rev. 1988, 88, 243.

[5] S. Gómez-Ruiz, E. Hey-Hawkins, Coord. Chem. Rev. 2011, 255, 1360.

[6] For reviews, see: a) M. Peruzzini, R. Abdreimova, Y. Budnikova, A. Romerosa, O. J. Scherer, H. Sitzmann, J. Organomet. Chem.
2004, 689, 4319; b) M. Peruzzini, L. Gonsalvi, A. Romerosa, Chem. Soc. Rev. 2005, 34, 1038; c) J. S. Figueroa, C. C. Cummins, Dalton Trans. 2006, 2161; d) B. M. Cossairt, N. A. Piro, C. C. Cummins, Chem. Rev. 2010, 110, 4164; e) M. Caporali, L. Gonsalvi, A. Rossin, M. Peruzzini, Chem. Rev. 2010, 110, 4178.

[7] a) O. J. Scherer, T. Brück, Angew. Chem. Int. Ed. Engl. 1987, 26, 59; Angew. Chem. 1987, 99, 59; b) M. Detzel, T. Mohr, O. J. Scherer, G. Wolmershäuser, Angew. Chem. Int. Ed. Engl. 1994, 33, 1110; Angew. Chem. 1994, 106, 1142.

[8] a) J. Bai, A. V. Virovets, M. Scheer, Science 2003, 300, 781; b) C. Heindl, E. V. Peresypkina, A. V. Virovets, W. Kremer, M. Scheer, J. Am. Chem. Soc. 2015, 137, 10938; c) C. Heindl, E. Peresypkina, A. V. Virovets, I. S. Bushmarinov, M. G. Medvedev, B. Krämer, B. Dittrich, M. Scheer, Angew. Chem. Int. Ed. 2017, 56, 13237; Angew. Chem. 2017, 129, 13420; d) E. Peresypkina, C. Heindl, A. Virovets, H. Brake, E. Mädl, M. Scheer, Chem. Eur. J. 2018, 24, 2503; e) H. Brake, E. Peresypkina, C. Heindl, A. V. Virovets, W. Kremer, M. Scheer, Chem. Sci. 2019, 10, 2940.

[9] a) G. Capozzi, L. Chiti, M. Di Vaira, M. Peruzzini, P. Stoppioni, J. Chem. Soc. Chem. Commun. 1986, 1799; b) M. Di Vaira, P. Stoppioni, S. Midollini, F. Laschi, P. Zanello, Polyhedron 1991, 10, 2123 ; c) M. Peruzzini, J. A. Ramirez, F. Vizza, Angew. Chem. Int. Ed. 1998, 37, 2255; Angew. Chem. 1998, 110, 2376; d) P. Barbaro, M. Peruzzini, J. A. Ramirez, F. Vizza, Organometallics 1999, 18, 4237; e) P. Barbaro, A. Ienco, C. Mealli, M. Peruzzini, O. J. Scherer, G. Schmitt, F. Vizza, G. Wolmershäuser, Chem. Eur. J. 2003, 9, 5195; f) M. Di Vaira, P. Frediani, S. S. Costantini, M. Peruzzini, P. Stoppioni, Dalton Trans. 2005, 2234; g) M. Di Vaira, M. Peruzzini, S. S. Costantini, P. Stoppioni, J. Organomet. Chem. 2006, 691, 3931; h) P. Barbaro, M. Di Vaira, M. Peruzzini, S. S. Costantini, P. Stoppioni, Chem. Eur. J. 2007, 13, 6682 ; i) P. Barbaro, C. Bazzicalupi, M. Peruzzini, S. S. Costantini, P. Stoppioni, Angew. Chem. Int. Ed. 2012, 51, 8628; Angew. Chem. 2012, 124, 8756; j) M. V. Butovskiy, G. Balázs, M. Bodensteiner, E. V. Peresypkina, A. V. Virovets, J. Sutter, M. Scheer, Angew. Chem. Int. Ed. 2013, 52, 2972; Angew. Chem. 2013, 125, 3045; k) M. Bispinghoff, Z. Benkő, H. Grützmacher, F. D. Calvo, M. Caporali, M. Peruzzini, Dalton Trans. 2019, 48, 3593.

[10] a) E. Mädl, M. V. Butovskii, G. Balázs, E. V. Peresypkina, A. V. Virovets, M. Seidl, M. Scheer, Angew. Chem. Int. Ed. 2014, 53, 7643; Angew. Chem. 2014, 126, 7774; b) E. Mädl, G. Balázs, E. V. Peresypkina, M. Scheer, Angew. Chem. Int. Ed. 2016, 55, 7702; Angew. Chem. 2016, 128, 7833; c) M. Piesch, S. Reichl, M. Seidl, G. Balazs, M. Scheer, Angew. Chem. Int. Ed. 2019, https://doi. org/10.1002/anie.201908397; Angew. Chem. 2019, https://doi.org/ 10.1002/ange.201908397.

[11] a) J. S. Figueroa, C. C. Cummins, J. Am. Chem. Soc. 2004, 126, 13916; b) J. S. Figueroa, C. C. Cummins, Angew. Chem. Int. Ed. 2004, 43, 984; Angew. Chem. 2004, 116, 1002; c) N. A. Piro, J. S. Figueroa, J. T. McKellar, C. C. Cummins, Science 2006, 313, 1276; d) B. M. Cossairt, M.-C. Diawara, C. C. Cummins, Science 2009, 323, 602; e) B. M. Cossairt, C. C. Cummins, Angew. Chem. Int. Ed. 2010, 49, 1595; Angew. Chem. 2010, 122, 1639; f) D. Tofan, B. M. Cossairt, C. C. Cummins, Inorg. Chem. 2011, 50, 12349; g) A. Velian, C. C. Cummins, Chem. Sci. 2012, 3, 1003.

[12] a) M. H. Holthausen, J. J. Weigand, Chem. Soc. Rev. 2014, 43, 6639; b) M. Donath, F. Hennersdorf, J. J. Weigand, Chem. Soc. Rev. 2016, 45, 1145 .

[13] a) K. Schwedtmann, G. Zanoni, J. J. Weigand, Chem. Asian J. 2018, 13, 1388; b) T. Krachko, C. Slootweg, Eur. J. Inorg. Chem. 2018, 2734.

[14] A. P. M. Robertson, P. Gray, N. Burford, Angew. Chem. Int. Ed. 2014, 53, 6050; Angew. Chem. 2014, 126, 6162.

[15] a) M. Alcarazo, Chem. Eur. J. 2014, 20, 7868; b) M. Alcarazo, Acc. Chem. Res. 2016, 49, 1797. 
[16] a) S. Yao, N. Lindenmaier, Y. Xiong, S. Inoue, T. Szilvási, M. Adelhardt, J. Sutter, K. Meyer, M. Driess, Angew. Chem. Int. Ed. 2015, 54, 1250; Angew. Chem. 2015, 127, 1266; b) S. Yao, T. Szilvasi, N. Lindenmaier, Y. Xiong, S. Inoue, M. Adelhardt, J. Sutter, K. Meyer, M. Driess, Chem. Commun. 2015, 51, 6153 c) F. Spitzer, M. Sierka, M. Latronico, P. Mastrorilli, A. V. Virovets, M. Scheer, Angew. Chem. Int. Ed. 2015, 54, 4392; Angew. Chem. 2015, 127, 4467; d) F. Spitzer, C. Graß1, G. Balázs, E. M. Zolnhofer, K. Meyer, M. Scheer, Angew. Chem. Int. Ed. 2016, 55, 4340; Angew. Chem. 2016, 128, 4412; e) F. Spitzer, C. Graß1, G. Balázs, E. Mädl, M. Keilwerth, E. M. Zolnhofer, K. Meyer, M. Scheer, Chem. Eur. J. 2017, 23, 2716.

[17] S. Yao, Y. Xiong, C. Milsmann, E. Bill, S. Pfirrmann, C. Limberg, M. Driess, Chem. Eur. J. 2010, 16, 436.

[18] S. Gómez-Ruiz, B. Gallego, E. Hey-Hawkins, Dalton Trans. 2009, 2915.

[19] C. G. P. Ziegler, T. M. Maier, S. Pelties, C. Taube, F. Hennersdorf, A. W. Ehlers, J. J. Weigand, R. Wolf, Chem. Sci. 2019, 10, 1302.

[20] K. Schwedtmann, J. Haberstroh, S. Roediger, F. Hennersdorf, A. Bauza, A. Frontera, J. J. Weigand, Chem. Sci. 2019, 10, 6868.

[21] a) I. Krossing, J. Chem. Soc. Dalton Trans. 2002, 3, 500; b) I. Krossing, I. Raabe, Angew. Chem. Int. Ed. 2001, 40, 4406; Angew. Chem. 2001, 113, 4544; c) M. Gonsior, I. Krossing, L. Müller, I. Raabe, M. Jansen, L. van Wüllen, Chem. Eur. J. 2002, 8,4475 .

[22] a) J. J. Weigand, M. Holthausen, R. Fröhlich, Angew. Chem. Int. Ed. 2009, 48, 295; Angew. Chem. 2009, 121, 301; b) J. J. Weigand, M. H. Holthausen, J. Am. Chem. Soc. 2009, 131, 14210; c) M. H. Holthausen, K.-O. Feldmann, S. Schulz, A. Hepp, J. J. Weigand, Inorg. Chem. 2012, 51, 3374; d) M. H. Holthausen, J. J. Weigand, Z. Anorg. Allg. Chem. 2012, 638, 1103.

[23] M. H. Holthausen, A. Hepp, J. J. Weigand, Chem. Eur. J. 2013, 19, 9895 .

[24] M. H. Holthausen, S. K. Surmiak, P. Jerabek, G. Frenking, J. J. Weigand, Angew. Chem. Int. Ed. 2013, 52, 11078; Angew. Chem. $\mathbf{2 0 1 3}, 125,11284$.

[25] U. Chakraborty, M. Modl, B. Mühldorf, M. Bodensteiner, S. Demeshko, N. J. C. van Velzen, M. Scheer, S. Harder, R. Wolf, Inorg. Chem. 2016, 55, 3065.

[26] U. Chakraborty, J. Leitl, B. Mühldorf, M. Bodensteiner, S. Pelties, R. Wolf, Dalton Trans. 2018, 47, 3693.

[27] The pathway of formation of $\mathbf{1 - i} \mathbf{P r} \cdot \mathbf{G a C l}_{\mathbf{3}}$ and $\mathbf{1 - M e s}$ is distinct from the synthesis of bicyclotetraphosphanes from $\mathrm{P}_{4}$ and cyclopentadienyl radicals previously described by Scheer and co-workers; see: S. Heinl, S. Reisinger, C. Schwarzmaier, M. Bodensteiner, M. Scheer, Angew. Chem. Int. Ed. 2014, 53, 7639; Angew. Chem. 2014, 126, 7769.

[28] a) E. Niecke, R. Rüger, B. Krebs, Angew. Chem. Int. Ed. 1982, 21, 544; Angew. Chem. 1982, 94, 553; b) R. Riedel, H.-D. Hausen, E. Fluck, Angew. Chem. Int. Ed. 1985, 24, 1056; Angew. Chem. 1985, 97, 1050; c) E. Fluck, R. Riedel, H.-D. Hausen, G. Heckmann, Z. Anorg. Allg. Chem. 1987, 551, 85; d) J.-P. Bezombes, P. B. Hitchcock, M. F. Lappert, J. E. Nycz, Dalton Trans. 2004, 499; e) A. R. Fox, R. J. Wright, E. Rivard, P. P. Power, Angew. Chem. Int. Ed. 2005, 44, 7729; Angew. Chem. 2005, 117, 7907; f) M. Donath, E. Conrad, P. Jerabek, G. Frenking, R. Fröhlich, N. Burford, J. J. Weigand, Angew. Chem. Int. Ed. 2012, 51, 2964; Angew. Chem. 2012, 124, 3018; g) N. A. Giffin, A. D. Hendsbee, T. L. Roemmele, M. D. Lumsden, C. C. Pye, J. D. Masuda, Inorg. Chem. 2012, 51, 11837; h) J. Bresien, C. Hering, A. Schulz, A. Villinger, Chem. Eur. J. 2014, 20, 12607; i) J. E. Borger, A. W. Ehlers, M. Lutz, J. C. Slootweg, K. Lammertsma, Angew. Chem. Int. Ed. 2014, 53, 12836; Angew. Chem. 2014, 126, 13050; j) J. Bresien, K. Faust, A. Schulz, A. Villinger, Angew. Chem. Int. Ed. 2015, 54, 6926; Angew. Chem. 2015, 127, 7030; k) J. Bresien, K. Faust, C. Hering-Junghans, J. Rothe, A. Schulz, A. Villinger, Dalton Trans. 2016, 45, 1998; 1) F. Hennersdorf, J. J. Weigand, Angew. Chem. Int. Ed. 2017, 56, 7858; Angew. Chem. 2017, 129, 7966.

[29] A structurally related, cationic bicyclo[1.1.0]pentaphosphane is described in Ref. [24]. Moreover, several unsymmetrically substituted bicyclo[1.1.0]tetraphosphanes have been described recently; see Ref. [28h-1].

[30] $\left[\mathrm{Cp}^{\mathrm{Ar}} \mathrm{Co}(\mathrm{cod})\right]$ was synthesized by reducing $\left[\mathrm{Cp}^{\mathrm{Ar}} \mathrm{Co}(\mu-\mathrm{X})\right]_{2}$ $(\mathrm{X}=\mathrm{Cl}, \mathrm{Br})$ with $\mathrm{KC}_{8}$ in the presence of COD in THF; see the Supporting Information for a detailed procedure.

[31] U. Chakraborty, F. Urban, B. Mühldorf, C. Rebreyend, B. de Bruin, N. van Velzen, S. Harder, R. Wolf, Organometallics 2016, 35, 1624.

[32] P. Pyykkö, M. Atsumi, Chem. Eur. J. 2009, 15, 12770.

[33] It is noteworthy that such a second diastereomer was not observed for 2-Cl-Cy (see Figure S93).

Manuscript received: July 18, 2019

Revised manuscript received: September 24, 2019

Accepted manuscript online: September 26, 2019

Version of record online: November 6, 2019 